\title{
FEMINISM AND CLASS POLITICS: A Round-Table Discussion
}

Clara Connolly and Lynne Segal, representing Feminist Review, talk with Michèle Barrett, Beatrix Campbell, Anne Phillips, Angela Weir and Elizabeth Wilson

In December 1984 Angela Weir and Elizabeth Wilson, two founding members of Feminist Review, published an article assessing contemporary British feminism and its relationship to the left and to class struggle. They suggested that the women's movement in general, and socialist-feminism in particular, had lost its former political sharpness. The academic focus of socialist-feminism has proved more interested in theorizing the ideological basis of sexual difference than the economic contradictions of capitalism. Meanwhile the conditions of working-class and black women have been deteriorating. In this situation, they argue, feminists can only serve the general interests of women through alliance with working-class movements and class struggle. Weir and Wilson represent a minority position within the $B$ ritish Communist Party (the $C P$ ), which argues that 'feminism' is now being used by sections of the left, in particular the dominant

'Eurocommunist' left in the $C P$, to justify their moves to the right, with an accompanying attack on traditional forms of trade union militancy.

Beatrix Campbell, who is aligned to the dominant position within the CP, has been one target of Weir and Wilson's criticisms. In several articles from 1978 onwards, and in her book Wigan Pier Revisited, Beatrix Campbell has presented a very different analysis of women and the labour movement. She has criticized the trade union movement as a 'men's movement', in the sense that it has always represented the interests of men at the expense of women. And she has described the current split within the CP as one extending throughout the left between the politics of the 'old' and the 'new': traditional labour movement politics as against the politics of those who have rethought their socialism to take into account the analysis and importance of popular social movements - in particular feminism, the peace and anti-racist movements. In reply to this debate, Anne Phillips has argued that while women's position today must be analysed in the context of the capitalist crisis, it is not reducible to the dichotomy 'class politics' versus 'popular alliance'. Michèle Barrett, in another reply to Weir and Wilson, has 
argued that they have presented a reductionist and economistic approach to women's oppression, which caricatures rather than clarifies much of the work in which socialist-feminists have been engaged.

To air these differences between socialist-feminists over the question of feminism and class politics, and to see their implications for the women's movement and the left, Feminist Review has decided to bring together the main protagonists of this debate for a fuller, more open discussion. For this discussion Feminist Review drew up a number of questions which were put to the participants by Clara Connolly and Lynne Segal. (Michèle Barrett was present in a personal capacity.) They cover the recent background to socialist-feminist politics, the relationship of feminism to Marxism, the role of feminists in left political parties and the labour movement, the issue of racism and the prospects for the immediate future. The discussion was lengthy and what follows is an edited version of the transcript.

LYNNE: Can we start with a brief comment on the general background to socialist-feminist politics in Britain now? What political context are we working in?

ANNE: The background to the situation is the enormous difference between the mid 1980s and the more optimistic period of the 1960 s and 70 s. Looking back, the 70 s were a time when not only the women's movement, but the whole of the trade union and socialist movement, were very confident. The Conservative Party was weak, almost paralyzed, and the left's victory over Edward Heath, for example, might have made us feel stronger than in fact we really were. Socialists and feminists were launching their attack against the sympathetic political post-war consensus that male unemployment should be low and the welfare state was in place.

Now, we are up against a determined, radically right-wing government. So socialist-feminists are having to come to terms with party politics at a time when it's the Labour Party that's weak rather than the Conservatives. That means that we are on the defensive because the consensus is being dismantled from the other side. So this has forced socialists and feminists into some quite difficult rethinking about the assumptions that we can make.

LYNNE: Yes, Anne has written about this fundamental 'rethinking' that's been going on among socialists and feminists. What does this willingness 'to relinquish long-cherished beliefs' really mean?

ELIZABETH: I want to take up this 'rethinking' in relation to Marxism rather than party politics. I think it's important to remember that in Britain Marxism is not a well-rooted tradition but an incredibly marginalized discourse. The Marxism of 1968 and after was rather 
febrile and quite momentary, yet it is often seen as some kind of orthodoxy. The politics of that time were based on a mixture of this rather superficial, somewhat academic Marxism and a very avant-garde or vanguardist kind of politics. One of the things I liked about the women's movement was its vanguardism. It posed all sorts of ultimate questions, questions about the family and sexuality and so on, that were thought too dangerous to pose. The reaction against that now is desirable in one sense, in that feminists are now more mindful of most women's experiences. But there are dangers too in becoming too populist - one minute the family's all right and the next minute Christianity's all right and the next minute any old thing is all right. That's a caricature, of course, but the ambivalences of populism do make it dangerous.

LYNNE: Taking up that theme of how feminist politics in general have moved on, I wonder if we could focus more specifically on socialist-feminism. Michèle has argued that socialist-feminism is less influential now than it used to be. Do you think that is true?

ANNE: Yes, there has been a decline in the influence of socialist-feminism in the $80 \mathrm{~s}$ in the popular conception of feminism. This is largely because socialist-feminists have concentrated on the problems of relating to socialist politics. That has become the main site for socialist-feminists, and while it may increase their influence within that context it inevitably decreases their influence outside of it. It is connected both to the collapse of national women's liberation movement conferences, after which socialist-feminism was no longer forced into a continual dialogue with feminists of different perspectives, and to general changes in the political context of Britain.

MICHĖLE: But I wouldn't want to overstate the decline in the influence of socialist-feminism. Clearly, radical and cultural feminism are more well known in society generally than socialist-feminism. Also I think it's true to say that within the women's movement the socialistfeminism of the 1970s has given way to feminist peace initiatives and to the specific demands of Black feminists. But many socialist-feminist battles have been won. Socialist-feminist positions are accepted by some trade unions, in some sections of the Labour Party, by the GLC and other municipal authorities. So it's more complicated than talk of a general decline suggests.

LYNNE: Is there any connexion between what's been happening to socialist-feminism and the emphasis in feminist thought in general since the mid 1970s on sexuality and male violence?

ELIZABETH: One disturbing aspect of this is the way in which some radical men have taken up the question of pornography. Half of those on the left who think they are sensitive to feminism have taken up the 
pornography issue often without being aware that it is one on which socialist-feminists disagree. Ken Livingstone, for instance, can say that Andrea Dworkin is the most wonderful feminist living as if there had been no debate at all around her book. While of course pornography is something to struggle against, to single out that particular aspect of feminism leads to quite a reactionary political position. It is populist. It is easier than it is to work out some actual policy about the family for the Labour Party.

BEATRIX: I have my criticisms about the way in which Ken Livingstone (and men like that, though there are not many of them) has assimilated feminism, but frankly, compared to the rest of them, I am not bothered. He is the only male politician in the labourist tradition who has taken responsibility for finding out what feminism is and for trying to do something about it in an institution over which he has some control. The GLC is an arena in which socialist-feminists have a very strong presence and this has impacted on the political culture that we all in London inhabit, and on municipal socialism elsewhere, and made a difference to the women employed by that local authority. The traditions of the Marxist movement and of the left today deserve a much heavier attack than he does.

As socialist-feminists we do not just disagree now about our relation to feminism (which I suppose we always did), but we also disagree, hugely, about socialism. In one sense socialist-feminism's influence has declined. In another sense it has been remarkably resilient, inventive, and will endure because it has affected areas of the labour movement that have power - the local authorities.

My main anxiety about socialist-feminism is that it has disengaged from feminism. It has taken no responsibility for the culture of the women's liberation movement, for some of the institutions that it has tried to create. Its habitual response to some of the things that it disagrees with is to scarper. That's reflected in Feminist Review itself. How the hell can you run a socialist-feminist magazine and not have a serious engagement with, for instance, Greenham Common, one of the most successful of feminist actions? Where was socialist-feminism at Greenham?

CLARA: How precisely has Greenham been a success?

BEATRIX: At a point when it was difficult to imagine forms of politics outside the institutions, it regenerated the radical traditions of direct action which had disappeared off the agenda of left politics during the 70s. Greenham was something completely different - to inhabit a piece of space permanently, to contest the opposition's right to hold it, to say we are going to stay and we are going to watch every move you make. And it drew on a culture of femininity and radicalized it. Initially, a lot of people had a problem with all the talk of embroidery, sticking things on the fence, grannies coming along, thinking about the future they 
wanted for their children. Yet it created an atmosphere in which it was possible to speak of your care for the planet and for those who live on it, ideas that are not always part of the vocabulary of the left.

In 1983, the year of the last General Election, there were proportionately more men against Cruise than there were women. After the weekend in which the Embrace the Base and the Dallas holocaust, 'The Day After', had saturation cover on the telly, women's views on Cruise changed dramatically. There was something like two to one women opposed to Cruise. So if it did nothing else, Greenham unhinged thousands of women from their support for the right at a crucial moment. The Tories were so worried about it that they chucked in millions to defeat CND in general and to discredit the women's peace movement in particular.

ELIZABETH: A general problem with our discussion is the assumption that our experiences have been similar. One thing that is seductive but

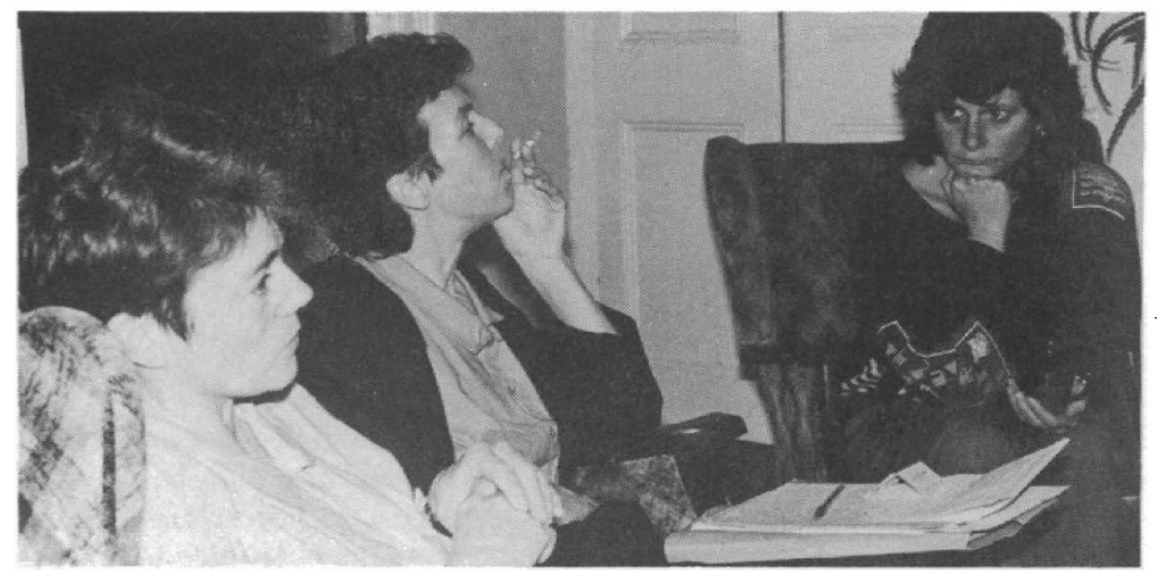

Anne Phillips, Beatrix Campbell, Lynne Segal.

dangerous about your sort of rhetoricism, Bea, is that you assume that there is a truth that we all know about, but I cannot honestly say that my experience has been the same as yours, or as Anne's for that matter. I am now more active in my union, where women are divided between the far left and the broad left in the classic sense, and we are even divided about feminist issues. It is one of those myths of the women's movement that every single trade unionist is this man thumping along in heavy boots and a donkey jacket shouting at women. My experience of the left has been more varied. In the other sphere of my activity, the cultural sphere, although there is a distancing between black women writers and white women writers, for example, there is much less antagonism. There is the space for people to do all sorts of things.

There is also a danger of sentimentalizing women's relationships when we all know that the women's movement has been riven with conflict. Not having been able to overcome those divisions politically is 
partly the reason we are in a weakened state now. If I compare my entry into the Communist Party in South Islington in 1974 to a lot of women's groups, including Red Rag (although there were many Communist Party women in it), then the women's groups were simply not up to the standard of that local party branch in the way that it dealt (in my case by Marie Betteridge) with new people coming in, and in the kind of sensitive political education it offered.

So a danger of this sort of debate is that it constructs a one-dimensional history far from actual, varied experience.

LYNNE: Michèle has said that the core of her disagreement with Elizabeth and Angie is that they want to integrate a feminist and a Marxist analysis at the most analytically abstract as well as at the political level, and she feels that this is not possible. Are Marxism and feminism incompatible at the theoretical level and is it useful to make a distinction between theory and political practice?

MICHÈLE: Although I don't think that Marxism and feminism are incompatible, sometimes their political objectives don't coincide, they conflict, and the history of the British labour movement is a history of much greater conflict on that issue than you have suggested, Elizabeth. Marxism can be extremely good at explaining the form that is taken by women's oppression in different societies but it does not really explain why it should be that in every known society women are oppressed. Marxism and feminism are different theories trying to explain different things and nobody has satisfactorily reconciled them.

A number of people have tried to work towards such a theoretical integration (I have done this in the past) and tried to argue for that because they see it as politically desirable. But I now think that this is not necessary and that we should recognize the different theoretical objectives of Marxism and feminism. It is far more important for us to understand the way in which class is, in a profound way, gendered, and to argue for a socialism that is informed by feminism.

ANGELA: I do not entirely agree with the way that Michèle has posed the problem in that I do not know that I accept that there is a coherent body of feminist theory (although I do have an idea of what would be described as a body of Marxist theory). The perspective from which Elizabeth and I wrote the New Left Review article was that we are Marxists but we are particularly concerned that women have been neglected historically - made invisible, as we used to say in the early days of the movement. We have to create the circumstances in which women can articulate and fight and organize for their own interests and desires, but that does not necessarily imply that there will be a distinctive feminist theory to explain the particular position of women or the construction of gender difference, although other theories such 
as psychoanalysis may be helpful and possibly integratewith Marxism.

Theory and practice must go together. It is dangerous to go along with the idea that we can support a shopping list of demands about women in this political climate without looking to the way in which those demands imply major structural changes not only in the organization of gender difference but in the organization of capitalist relations within our particular society.

MICHÈLE: Wouldn't you say that the concept of patriarchy (even if I have been critical of it) stood for feminist theory in general, that it is a straightforward position held by the vast majority of feminists to explain women's oppression and the way it benefits men?

ANGELA: It is a description.

MICHÈLE: It is a concept developed with considerable sophistication, detail and elaboration by feminists on analyses of various categories, whether economic, sexual, psychic or whatever. It is a big mistake to say that, because there is no single version of feminist theory I happen to agree with, there is no feminist theory. I do think there are major theoretical problems which are tackled by feminism which are different from the object of analysis of Marxism. If you deny the existence of feminist theory you also rule out the feminist problem.

ANGELA: The feminist problem - a political but also a personal problem - is to explain why we are here as we are, having the experiences that we do, and that very often it is oppressive to be a woman, that it is a process of denial, of exclusion, and that it is the opposite to men's experience.

ANNE: Because of the considerations raised by feminism I no longer think of myself as a Marxist. I would describe myself now as influenced by Marxism, or as basically agreeing with the Marxist analysis of the capitalist mode of production, but I have reached a point where it just does not help to say I am a Marxist or that I am a Marxist feminist. Marxism is a totalizing explanation of the world. If you drop from that to the idea that Marxism is a good explanation of certain things in the world, then it seems to me that that is not being a Marxist.

MICHÈLE: But it's very interesting, Anne, that even when you announce that you don't regard yourself as a Marxist you say at that same time that you agree with a Marxist analysis of capitalism. You are refusing some of the political corollaries of that analysis and some of its general claims. But you are acknowledging a fundamental Marxist influence in the way in which you see the world. I think that illustrates quite well the fact that socialist-feminism is profoundly influenced by Marx and Marxism. I don't share Elizabeth's defensive reaction to feminist criticism of Marx. 

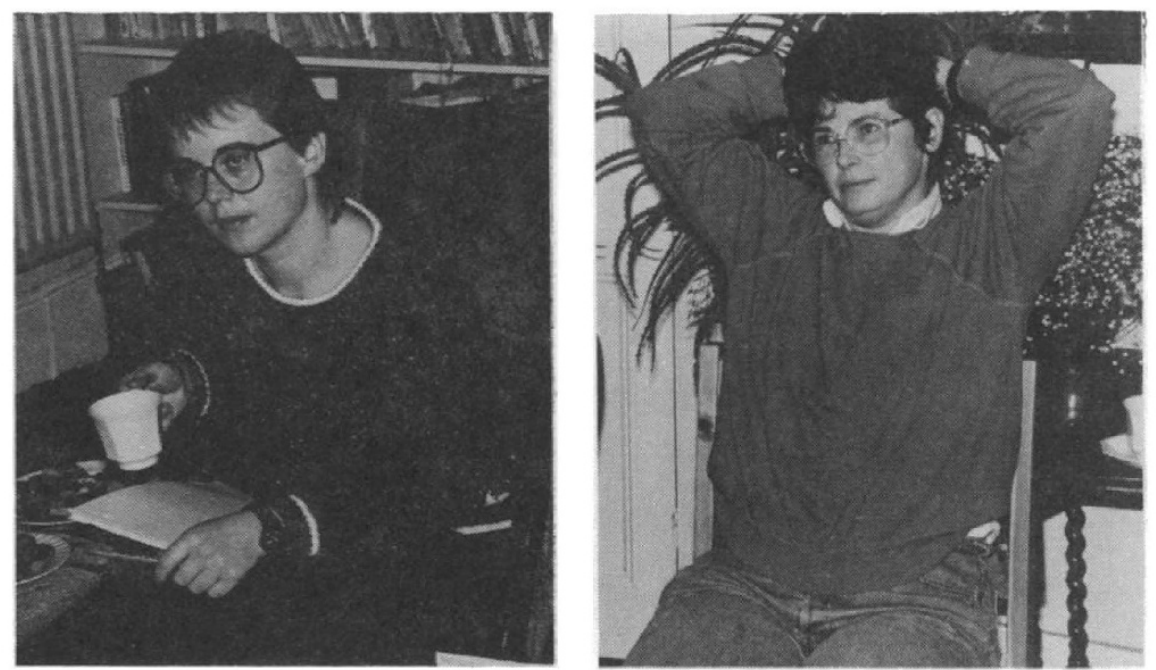

Clara Connolly (left) ,|Angela Weir (right).

CLARA: Black feminists have accused white feminists of an ethnocentric analysis which fails to tackle the issues of most concern to Black women. Would you agree with this?

ANNE: Unquestionably a lot of white feminist writing has taken as a paradigm the experience of white women and generalized from that. However, it is not so clear what the implications are if you correct that. If you take the example of part-time employment, the fact that it is predominantly white women's experience rather than Black women's experience does not mean that it is no longer a key feature for a feminist analysis of employment.

The other side of the issue is that Black feminists stress the relationship between the structures of racism and sexism, and the general structures of class exploitation, and the need for a political practice which acknowledges those competing pressures. Since that has obvious parallels with the competing priorities of gender and class for socialist-feminists it should be an area that is particularly fruitful. It should mean that it is easier for socialist-feminism to acknowledge the strength of the Black feminist position. However, it is possible to be too complacent here. When I read Black feminists' critiques, I find I am relieved that they are stressing the importance of class or of race as well as of being a woman because that strengthens my own arguments. And that can become a rather dishonest attempt to forge an alliance at a theoretical level without taking on the complexity of changing your own analysis.

MICHEेLE: Well, of course it is difficult to rethink one's own analysis. Mary McIntosh and I attempted to rethink some of our work from this point of view and many people are critical of what we came up with. 
But I do think that white socialist-feminists should really try to engage with the questions that Black feminists are raising. We can't just ignore their arguments. In some ways it might be easier for white feminists to take up positions in sympathy with Black separatism, but there is a danger of leaving one's own theory and politics untouched if you do that.

BEATRIX: The answer to the question is: yes. Typically, there are no Black women here today. But one of the advantages of feminism is that it starts from a questioning of certainties, and so we should be careful to preserve a tradition enabling us to be disposed to self-criticism about our ethnocentricity.

ANGELA: I think that there needs to be a Black political leadership and the racist barrier which prevents the emergence of that leadership is the problem we have to tackle. In concrete terms, there is a major threat from the Tory government, from Fowler on social services, and it is not just a white issue. Proposed social security legislation, like the presence test, in which you will have to show that you have a lawful presence in this country in order to be entitled to social security, attacks the Black immigrant population. As white feminists we are not going to be as sensitive to what is happening, so to resist that effectively there must be a dialogue with the Black community. In terms of theory, the Black sisters have voiced a far better internationalist perspective. They raise the issue of how an analysis of imperialism affects the traditions of white women in British society.

CLARA: Michèle and Anne are members of the Labour Party and Elizabeth, Angie and Bea are members of the Communist Party, although on different wings. Are there links between the new divisions in the Communist Party and in the Labour Party? Do these reflect a split between what Bea describes as old and new politics; that is, between traditional class politics and the politics of the popular movements? How does feminism connect the different positions?

MICHÈLE: I want to question this phrase, 'the links between the new divisions in the Communist Party and in the Labour Party'. The Labour Party left, as I understand it, is quite different from the position now associated with the Left Opposition in the Communist Party. There is a very strong Trotskyist identity on the Labour left. If there seems to be a mood of alliance between the Communist Party left and certain Trotskyist sections, what does that mean given that these are historically extremely different and divided political groupings?

It is widely held that the Communist Party has far more influence than its numbers would suggest. If you accept a straight Left Opposition versus Eurocommunist split in the Communist Party, what 
is the nature of the pressure that those two wings are trying to bring to bear on the Labour Party and on the labour movement more generally? One of my objections to Angie and Elizabeth's article was that it tried to export the CP split in a damaging and sectarian way to constituencies outside the Communist Party, including the women's movement.

ELIZABETH: I see it as exactly the opposite - not that I am dragging all these arguments into the feminist movement but that sections of the left use feminism to justify their own movement to the right. For several years now there have been various theoretical discourses (with a tendency towards idealism) which are not so much a critique of Marxism as a deconstruction of Marxism and of any kind of general theory of why everybody is in such a terrible mess. Given that we are all calling ourselves socialist-feminists, you cannot say that what goes on in the left in Britain (where the left is so tiny) can be of no importance to socialist-feminists. This left must be part of what we look at or try to influence. It is not we that invented the connexion. The connexion is there, isn't it?

BEATRIX: Clearly, there have been splits across the whole of the left. At what point do elements within all those different formations of the left find each other?

Since 1956 the leadership has been trying to manage a split Communist Party, a pro-Soviet element (about a third of the membership), the centre and, to the left (especially since 1968), a miscellaneous set of positions. In the 70s the party split again. It had been besieged by a critique of militant labourism from the left and from the women's liberation movement. An element of the centre, appalled by the assimilation of new social policies, found itself more in kinship with the pro-Soviet element in the Communist Party. Despite their differences they shared a commitment to the traditions of labourism. In the late $70 \mathrm{~s}$ a realignment across and outside of the Communist Party took place. 1984 saw the consummation of a labourist ultra-leftism, especially in the Labour Party, which we saw in practice in the miners' strike, in the conduct of the campaign against rate-capping and in the quite unpredictable response of the left to demands put by women. The old traditions of Stalinism and Trotskyism found they shared a number of common principles. The splits in the Labour Party and in the Communist Party are not the same, but part of the realignment represents a defence of militant, economistic class consciousness, of a conservative class consciousness.

ANNE: Class militancy has not been at the centre of the Labour Party in the way in which it is built into the definition of the Communist Party, and the Labour Party has had a very different scenario over the last ten to fifteen years. Through the 70s the Bennite left emerged and introduced a more traditional class politics and at the same time 
linked with new popular movements. Benn actually went further in terms of his identification with the women's movement than a lot of the subsequent 'soft' left have done, perhaps because his notion of class politics was premised on the notion of real grassroots worker democracy. When that left was effectively defeated within the Labour Party, or at least pushed very much to the margins, it left feminism totally confused as to who its allies were. The feminists in the Labour Party have either been in it for decades, fighting around various issues, or they have entered in order to push for more radical kinds of transformation. They tend to be on the left and to be suspicious of Kinnock for trailing on the success of the Tory Party rather than pursuing a new alternative. Nonetheless, feminism has been part of that critique of the labourist tradition which Kinnock himself also represents. It is probably quite significant that those women who have been primarily involved around the issue of increasing the representation of women within the Labour Party, though in practice they tend to have an anti-Kinnock line, have been very careful to say that they are only organizing around that single platform. It is as though feminist politics within the Labour Party have been narrowed down to that particular area. That reflects the difficulty of constructing a coherent feminist politics in the Labour Party, given the way in which your enemies and your allies seem to be so different along different axes.

ANGELA: I do not agree with the terms of this question at all. To start from my own experience, I was suspended from the Communist Party in December/January (1984-85). I am not allowed to hold any position whatsoever in the party because of my suspect political views. Now that means, for instance, that I was told by the (now) London District Committee that I wasn't allowed to play any part in organizing the lesbian and gay collective within London - because I did not sufficiently understand the political importance of new social forces like the lesbian and gay movement. I was told this by a completely straight committee. I think it's ridiculous for the Communist Party to be telling me that.

Why have there been these extraordinary measures to shorten and foreclose discussion? Clearly, it is because there has been some crisis. Very simply, the membership of the Communist Party continues to decrease and the response of the present leadership has been to avoid its traditional method of work, of seeking the development of the movement through the trade unions, and to look instead to influence the Labour Party at a political level. That brings us to the crisis in the Labour Party. What is the nature of that? As we argued in the New Left Review article, there is a crisis of social democracy. Politically, it is expressed as whether either a Conservative Party or a Labour Party that advocates traditional consensus can achieve power in Britain today. Economically, it is expressed by the question of whether it is possible, through what has traditionally been described as Keynesian 
policies, to have full employment or even moderately full employment in Britain today. Is it possible to stop the slide of the standard of living in this country? In Italy there is now a higher standard of living amongst the working class than there is here. People are desperately looking around for answers. And that crisis has hit the Labour Party very dramatically. There is an attempt by sections of the Labour Party, supported and I think closely influenced by the Communist Party, to create a new social democratic consensus. Feminism is important because it is being used as a constituency which can be mobilized for this 'new' form of politics. In fact, it is a return to the old politics, the old right labourism which we have criticized.

ELIZABETH: I do not understand why people are socialists if they have nothing good to say about the socialist tradition. One has to look at the relation between feminism and socialism as a two-way street and say that in some ways the socialist tradition has things to teach feminism

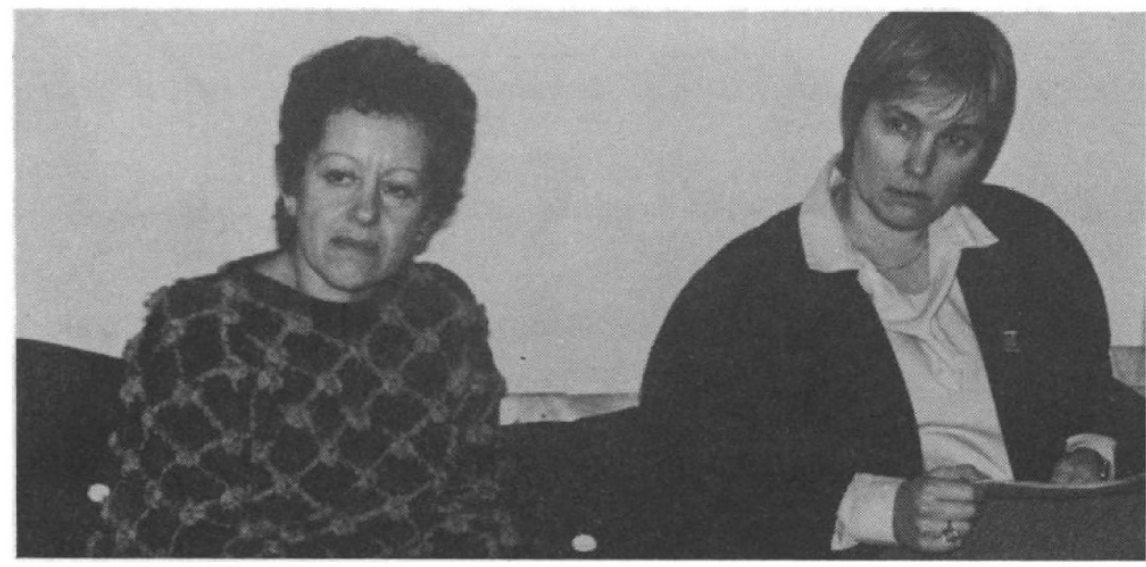

Elizabeth Wilson, Michele Barrett.

in terms of organization. We have heard nothing but criticism of the labour movement over the last six or seven years from feminists. Yet feminists do not seem to have found a way of dealing with disagreements among themselves. We have to find a way of engaging in debate without appearing to be insulting.

BEATRIX: We can all remember these horrible arguments with revolutionary feminists about this, that and the other, but in the socialist movement we are struggling with 100 years of history in which there has been constant conflict between the interests of men and the interests of women. Your tone is disingenuous, Elizabeth, because your criticisms of feminism have been ferocious. I am not concerned with 'opposing' the trade union movement but with transforming it, so that it is a place in which women can function and express their political priorities. The defeat of feminist objectives within the working-class movement has produced conservatism, in the 
forms of economism, chauvinism and managerialism of both right and left.

CLARA: We're obviously moving on the question that we wanted to discuss about the labour movement. Bea has described the labour movement as 'the men's movement'. What do you mean by that and what implications does it have for socialist-feminism?

BEATRIX: It's a men's movement in this sense. Go to the TUC any one year and you can count the few women that are there. Go to the Tory Party conference and the place is full of them, even though its priorities support the economic privilege of men. The labour movement's demands reflect the defeat of women's presence within the trade union movement. That's all I meant. It doesn't mean that it's not a movement that women are in, and that we shouldn't try and take over. The trade union movement added abortion to its agenda, it will add sexual harassment to it, some unions will even take on the issues of carers' leave, but the real crunch comes when you challenge the traditions of collective bargaining because of the way they encompass and reproduce women's economic inequality. Those women in the trade union movement who are trying to use equal value, for example, to challenge that are having a very hard time at the moment because they are challenging the male chauvinist priorities. Now we have to take responsibility for that.

MICHÈLE: I've never really understood, Bea, why you think collective bargaining in itself is such a problem - a lot of people would see it just as a mechanism. Your argument is surely much stronger over the whole general philosophy of differentials in trade unionism. It's based on the idea of strong groups bringing up the weaker ones. It's based on an assumption of full employment and stable technology. It's a strategy that's very vulnerable to the effects of deskilling and undercutting. Even leaving aside the feminist case, it's been a self-defeating strategy in the labour movement's own terms. Surely a much better, as well as less divisive, strategy would be to try and defend a minimum wage for everyone?

ANGELA: It is quite true to say trade unions are male dominated. All the decision-making levels tend to be dominated by white men. That seems to me to be true of all institutions in our society. That is not an argument for devaluing the position of trade unions or for calling them a men's movement. It is a problem we have to struggle with and we have to reach a position where women and Black men and Black women are at all levels of the trade union leadership. And for that you also have to look to other political movements.. It was the women's movement that led the TUC to adopt the abortion demand which, in 
turn, was one of the key factors preventing restrictive private legislation.

I think there's been quite a lot of progress within the trade union movement in that area, and so, in my own union which is NALGO, there's been a very active lesbian and gay group which I think has been quite successful in raising discussion about issues affecting lesbian and gay members, in exposing what lesbians now call homophobia and in fighting for concrete policies to improve the lives and conditions of lesbian and gay members. Now that development has been made possible by the existence of feminism, and we had to fight for it, but people have listened and I think that trade unions essentially are, at the end of the day, nearly all democratic organizations. And there aren't very many democratic organizations within our society, very few indeed. And so it is possible, if you are together and if you struggle on, to actually affect quite fundamental changes. So there have been changes, although not everything's perfect.

When we come to the debate about incomes policy, raised in Bea's work, I am very clear that I do not support incomes policy. I support free collective bargaining and I have always supported the demand for a minimum wage. But a minimum wage is no substitute for strong, collective trade union organization, Michèle. The trade union movement has been weak on how to increase the productive capacity of the country to improve everybody's standard of living, it has not always been good on representing Black workers, women, low paid men, not even on representing more highly paid men. It has rested on its laurels in certain sectors, and its biggest weakness is its political weakness: it has no political demands on how the economy should be restructured.

BEATRIX: I never supported incomes policy. What I have said is that women face a situation in which the practice of free collective bargaining has worked against them. It is incumbent on us to formulate a feminist economic strategy that suits people in a workplace and also assimilates experience outside the workplace - and that involves transforming the relationship between men and women. And I don't know what's wrong with that.

ELIZABETH: What's wrong with it, Bea, is that you're not saying it in a vacuum. Either you are effectively supporting incomes policy without admitting it or you are talking hot air because you do not say what the feminist economic strategy is.

BEATRIX: Sorry, I did. 


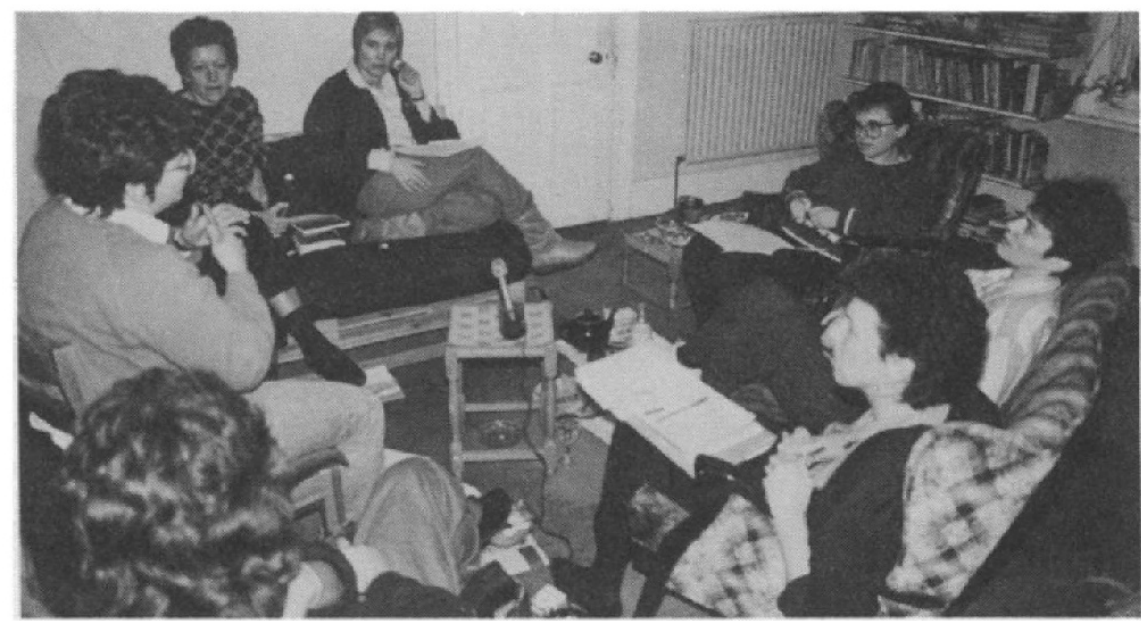

CLARA: Let us move on. Have women anything to hope from a future Labour government led by Neil Kinnock?

ANNE: I am not myself convinced that there is much basis for feminist optimism. So far, Kinnock has been concerned to present Labour Party issues in an acceptable and popular form rather than indicating that he is interested in reassessing policy. There is very little suggestion in his presentation of the Labour Party as the party of the welfare state and of the caring society that he has taken on board feminist critiques of what the welfare state has actually meant for women since it was introduced after the Second World War.

MICHEेLE: Anything you say about Kinnock has to be read against the background. After the 1983 election I joined the Labour Party, because I decided that I would rather see a Labour government - even a right-wing one under Healey or Hattersley - than go on taking a pure leftist position and have another dose of Thatcherism. Or have the Alliance, which is probably a greater danger. Kinnock is certainly appalling on class issues, lacking in integrity, and his strategies are often determined by a cynical assessment of the public response they will receive. But there are one or two areas where he is more refreshing. He seems to be genuine about disarmament and anti-apartheid, and it is encouraging to see Jo Richardson and the shadow Ministry for Women.

ANGELA: Kinnock believes that only by going further and further to the right and effectively leaving control of the essential issues to people like Hattersley and Healey can he be credible enough to win a general election. But I believe that the Labour Party only wins on crusading left policies which mobilize political energy and will. Labour's economic policy is crucial for women. In Britain, more and more control is going to the multinationals, jobs are being exported at 
a rapid rate, investment is flying away from this country and what we are seeing is the creation of a one-tier service sector which is not ancillary to manufacture and which is now the major economic base. Unless Kinnock goes into the next general election with an economic policy that challenges those developments he will not achieve anything.

BEATRIX: The Labour Party Conference showed that it has been a complete disaster for the non-Trotskyist left in the Labour Party to have allowed itself to be hijacked by the far left in the way that it did. Because it refused to take responsibility for that, it refused to take responsibility for Militant in particular. Kinnock did. And he did it in a way that is characteristic of him, like a bull in a china shop. The problem for us about Kinnock is that he is completely unreconstructed. It is as if he has not even cottoned on that the left outside the Labour Party existed and has made the running over the last fifteen years.

There is a real crisis for the left in the Labour Party, especially because the right is gathering itself together again and it is not stupid. It is not the old, cold war right of the 50s. It is a thoughtful, clever, educated, deeply pessimistic right. Meanwhile the left says that nationalization equals socialism and refuses to engage with most people's experience - that the Labour Party, when in power, disappoints and depresses. It does not empower people.

But.I do think it is interesting that, for the first time, we have a shadow cabinet that is trying to evolve feminist policies, and that there are possibilities in the reconstruction of the Labour leadership that make it better than anything we have seen, in our lifetimes anyway. What really excites me is that here we are, knocking on the end of the twentieth century, in a situation where we must create a politics that expresses the huge transformations over the last fifty years, the transformations in women's relation to the economy, women's relation to wages, women's relation to men and women's appearance on the political agenda.

CLARA: Can we take one or two final comments on feminism's future in the light of this question?

ELIZABETH: What disturbs me is that we have skirted around the question of the women's agenda. It is important for the Labour Party to have policies which will win a general election from a progressive position, but I do not think there is any agreement in this room as to what those policies are. There is an urgent need for a stronger left women's movement that can or would hammer out those policies and make them coherent enough to be taken on by the Labour Party. For example, I am not opposed to central state planning in the way that many neo-socialists are. I think you have to have it, but not 
administered in the old way. It has to be done to prioritize women's needs. You need the new and the old. For example, you have to have municipal housing but of a different kind, not simply the sale of council houses.

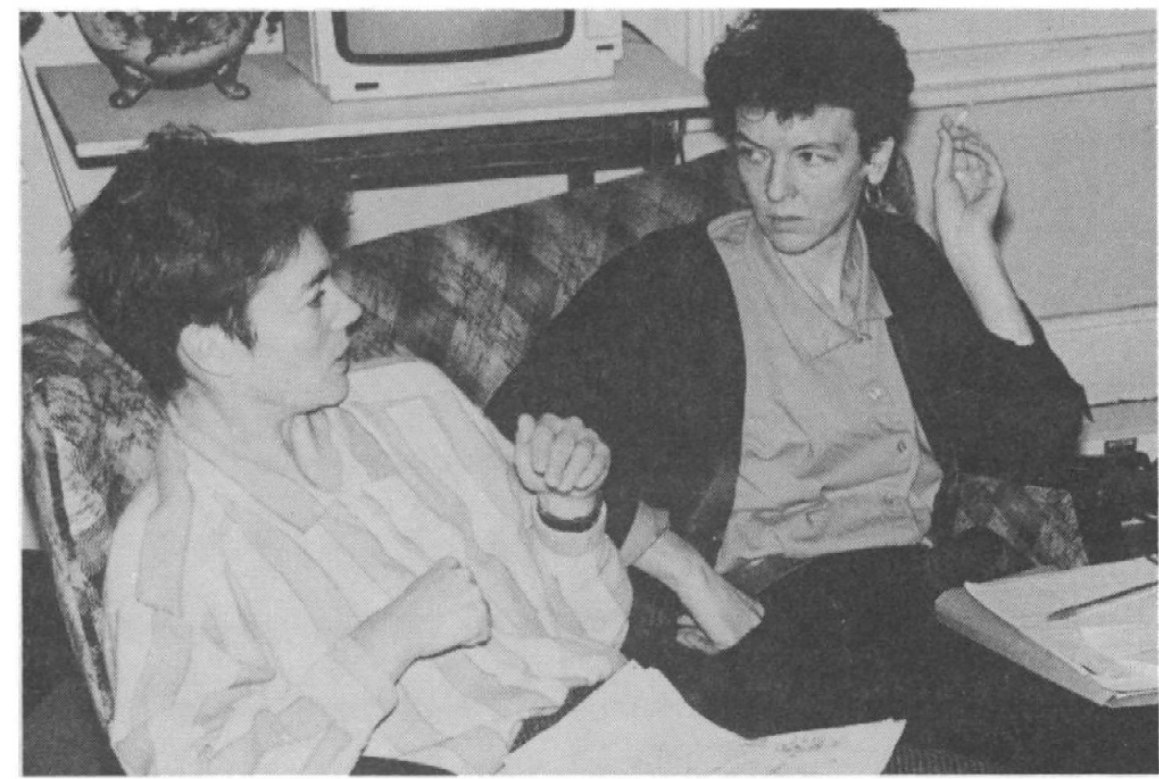

Anne Phillips, Beatrix Campbell.

ANNE: There are a whole range of other feminist areas in addition to Bea's example of Greenham Common which means that we are not in a position to specify what the priorities are in terms of women. But if you think about the issues there is a real problem about the separation of feminist politics into strands which oversimplify the issues. Not only does that include radical feminism, it includes a new kihd of respectable feminism which defines its politics around women and does not connect with any other political concerns. Socialist-feminism has ghettoized itself from interaction with non-socialist-feminist debates.

I do not think our feminism is being used to make us abandon our socialism. If anything, the extent to which we are engaged in debates with socialism means we are not constantly challenged or reinforced in terms of what feminist demands we want to make. The split in feminist politics potentially creates a really difficult situation. I would like national conferences again so there would be a forum in which to meet and in which to renew and re-create our political voice.

\section{Notes}

Feminist Review would like to thank Marsha Rowe for transcription and editorial work on this discussion. 


\section{References}

BARRETT, Michèle (1980) Women's Oppression Today London: Verso.

BARRETT, Michèle (1983) 'Marxist-Feminism and the Work of Karl Marx' in Marx. 100 Years On London: Lawrence \& Wishart.

BARRETT, Michèle and McINTOSH, Mary (1985) 'Ethnocentrism and SocialistFeminist Theory' Feminist Review No. 20.

BARRETT, Michèle (1985) 'A response to Weir and Wilson' New Left Review No.150.

CAMPBELL, Beatrix and CHARLTON, Valerie (1978) 'Work to Rule' Red Rag.

CAMPBELL, Beatrix (1980) 'United We Fall' Red Rag.

CAMPBELL, Beatrix (1984) Wigan Pier Revisited London: Virago Press.

CAMPBELL, Beatrix (1985) 'Politics "Old" and "New"' New Statesman 8 March.

FINE, Ben, HARRIS, Laurence, MAYO, Marjorie, WEIR, Angela and WILSON, Elizabeth (1984) Class Politics: An Answer To Its Critics London: Central Books.

PHILlIPS, Anne (1983) Hidden Hands London: Pluto Press.

PHILLIPS, Anne (1985) 'Class Warfare' New Socialist No. 24.

PHILlIPS, Anne (to be published February 1987) Divided Loyalties: The Dilemmas of Sex and Class London: Virago Press.

WEIR, Angela and McINTOSH, Mary (1982) 'Towards a Wages Strategy for Women' Feminist Review No. 10.

WEIR, Angela and WILSON, Elizabeth (1984) 'The British Women's Movement' New Left Review No. 148.

WILSON, Elizabeth (1980) 'Beyond the Ghetto: Thoughts on Beyond the Fragments' Feminist Review No. 4.

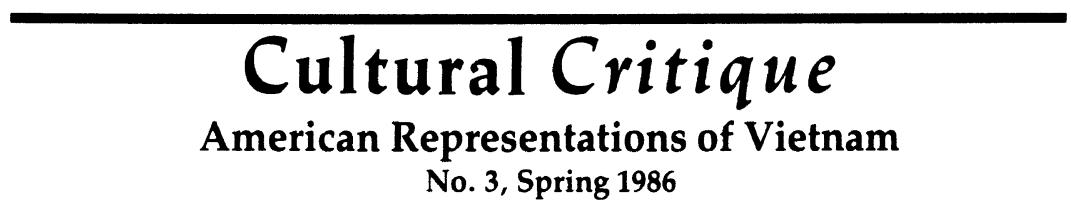

Scholars and critics in many disciplines have begun to study the great variety of documents, personal accounts, and stylized representations of America's war with Vietnam. In many ways, it was a war waged by various media as well as in actual combat, and the aftermath of this war continues to haunt us with difficult questions about how the representation of another culture shapes foreign policy and public opinion. This special issue of Cultural Critique offers various approaches to these practical and theoretical issues in the American representations of the Vietnam War.

John Carlos Rowe and Richard Berg, Viet- Richard Berg, Coming Home: The Veteran on nam in the Academy: Observations on the Rhetoric of Scholarship

John Carlos Rowe, Documentary Styles in the American Representation of Vietnam

Michael Clark, Snapshots: Remembering Vietnam

Claudia Springer, Military Propaganda: Defense Department Films from World War II to Vietnam Television and in Film

Noam Chomsky, Reflections on the Indochina Wars

Philip Kuberski, Genres of Vietnam

John M. Jakaitis, Two Versions of an Unfinished War: Dispatches and Going after Cacciato

W. D. Ehrhart, Poetry

Subscriptions: Check or money order (in U.S. dollars) should be made payable to $\mathrm{Cul}$ tural Critique and sent to Cultural Critique, English Dept., University of Minnesota, 207 Church St. S.E., Mpls., MN 55455.

$\begin{array}{llll}\text { Individuals } & \$ 15(1 \mathrm{yr} .) & \$ 30(2 \mathrm{yr} .) & \$ 45(3 \mathrm{yr} .) \\ \text { Institutions } & \$ 30(1 \mathrm{yr} .) & \$ 60(2 \mathrm{yr} .) & \$ 90(3 \mathrm{yr} .)\end{array}$

